\title{
PERFORMANCE ASSESSMENT OF PHOSPHORIC ACID FUEL CELL - THERMOELECTRIC GENERATOR HYBRID SYSTEM WITH ECONOMIC ASPECT
}

\author{
Fatma Gül Çelik ${ }^{1}$ Emin Açıkkalp ${ }^{1 *}$, Hasan Yamik ${ }^{1}$
}

\begin{abstract}
Purpose of this paper is to evaluate phosphoric acid fuel cell (PAFC) - thermoelectric generator hybrid system with economic and thermoeconomic point of view. Firstly, basic equations of PAFC, thermoelectric generator and hybrid system are described. Secondly, basic performance parameters like power output, energy efficiency, exergy efficiency and exergy destruction rates are investigated. Finally, cost equations are set up to determine economic results of the considered system, in addition to that, these system are considered by using EXCEM analysis. According to results, the maximum total cost of the hybrid system is obtained $j=10900 \mathrm{am}^{-2}$, exergy loss ratio to capital cost $(e c)$ of the hybrid system increases dramatically after the point where is $j=$ $11000 \mathrm{am}^{-2}$. Maximum power density, maximum energy efficiency and of the hybrid system are $8735.340 \mathrm{wm}^{-2}$, $81.35 \%$ and $86.6 \%$ respectively.
\end{abstract}

Keywords: Phosphoric Acid Fuel Cell, Thermoelectric Generator, Hybrid System, Economic Evaluation, EXCEM Analysis.

\section{INTRODUCTION}

Fuel cell technology is the conspicuous technology because of their nearly harmless to environment, relatively higher efficiency and their flexible fuel option. Nowadays, one of the most important problem of engineers and scientists are design to systems that convert to energy as most efficiently that enable us environmental friendly usage of them. Efficiency of a heat engine are restricted by the Carnot efficiency, however, this limitations is not valid for fuel cells. Because, fuel cell generates electricity in fuel cell by electrochemical reaction. Irreversible fuel cells including Solid oxide fuel cells (SOFC), molten carbonate fuel cell (MOFC), proton exchange membrane (PEM) fuel cell, phosphoric acid fuel cell (PAFC) and direct carbon fuel cell (DCFC) are investigated [1-5]. Zhang et al. considered PAFC in [5], they investigated cell voltage for different parameters including temperature, resistances, power and efficiency of the fuel cell according to current density, load resistance and mole fraction. They defined the optimum operating conditions.

Another opportunity offered by fuel cells are that heat rejected by the fuel cell can be used in another process and fuel cell - heat engine/refrigeration hybrid systems may be designed. In last decade, irreversible fuel cell and hybrid systems have been gained attention. In ref. [6], a hybrid PAFC- absorption refrigerator system was investigated. Power densities, efficiencies are studied under different conditions like temperature, pressure and phosphoric acid mole fraction. General performance characteristics and optimum criteria of the hybrid system are shown. PAFC-heat driven refrigerator cycle was taken into account in ref. [7]. System was researched for power density and efficiency and variable parameters were defined according to current density and refrigeration temperature, finally optimum conditions and performance characteristics were obtained. Performance of different fuel cell hybrid systems can be found literature; in refs. [8-10] fuel cell- Stirling, in refs. [11-15] fuel cell - heat engine, in refs. [16-25] fuel cell- Brayton, in refs. [26,27] fuel cell-Braysson hybrid systems were investigated for different conditions and performance criteria. In addition, novel hybrid systems including fuel cell- thermionic generator and fuel cell - Super critical $\mathrm{CO}_{2}$ - Organic Rankine cycle can be seen in refs. [28, 29].

Thermoelectric generators may be an alternative for creating hybrid system with fuel cells. They have several advantageous like; they don't have moving part, noiseless and they are not required maintenance

This paper was recommended for publication in revised form by Regional Editor Hakan Demir 
frequently. A thermoelectric generator is used heat to generate electricity based on the Seebeck effect and similarly they can be utilized as cooler on the principle of the Peltier effect. Some authors have been researched about optimization of thermoelectric devices [28-45].In the open literature, one can find papers about fuel cellthermoelectric generators hybrid systems. Chen et al, analyzed PAFC-thermoelectric hybrid system for the maximum power output conditions [46]. Zhao et. al. investigated direct carbon fuel cell-thermoelectric generator hybrid system [47]. Chen et al. analyzed a PEM- thermoelectric hybrid system in terms of power output and efficiency [48]. Another alternative to evaluate and design thermal cycles is finite time thermodynamics and constructional optimization. Some example of these may be found in [49-53] and these methods can be applied for the fuel cell hybrid systems widely.

In the open literature, authors are no aware of any study about PAFC- thermoelectric hybrid system in terms of economical and thermoeconomic aspects. Such techniques seek to determine of the appropriate allocation of economic resources so as to optimize the design and/or operation of a system; and/or the economic feasibility and profitability of a system [54]. In this paper, this shortage is tried to be completed. Firstly, thermodynamic relations are expressed for the fuel cell and thermoelectric generator. Secondly, PAFCthermoelectric generator hybrid system is analyzed with regard to power output, energy efficiency, exergy efficiency and exergy destruction rate. After these, cost of the hybrid system and thermoeconomic analysis are performed. EXCEM method [54] is chosen for the thermoeconomic evaluation. Results are obtained numerically, some important outcomes are discussed and suggestions are made.

\section{THERMODYNAMIC ANALYSIS}

PAFC is made of phosphoric acid as electrolyte and two electrodes which are anode and cathode. Air is provided to cathode and hydrogen is provided to anode and electrochemical reaction occurred in the fuel cell is $\mathrm{H}_{2}+1 / 2 \mathrm{O}_{2} \longrightarrow \mathrm{H}_{2} \mathrm{O}+$ heat + electricity. This produced heat resulted from the electrochemical reaction that can be used in another process. Operating temperature of PACF is about $150-200{ }^{\circ} \mathrm{C}$ which can be used in cogeneration applications for buildings and low temperature processes. Schematic of the hybrid system is shown in fig.1. In this paper, PAFC - thermoelectric hybrid system is analyzed in terms of economical aspect. Firstly, equations for fuel cell are presented. Maximum theoretical potential or Nernst equation is [5]:

$$
U_{r e v}=-\frac{\Delta g^{o}}{n_{e} F}+\frac{R T}{n_{e} F} \ln \left(\frac{p_{H_{2}}\left(p_{O_{2}}\right)^{0.5}}{p_{\mathrm{H}_{2} \mathrm{O}}}\right)
$$

Overpotentials cause the irreversible losses. These are activation overpotential described as activation overpotential, concentration overpotential and ohmic overpotential are shown in eqs. (2-4) respectively [5].

$$
\begin{gathered}
U_{a c t}=\frac{R T}{\alpha n_{e} F} \ln \left(\frac{j}{j_{o}}\right) \\
U_{c o n}=m e^{(n j)} \\
U_{o h m}=j \frac{t_{\text {ele }}}{\kappa}
\end{gathered}
$$

where $j$ is operating current density, $j_{\mathrm{o}}$ is exchange current density, $R$ is the universal gas constant, $\alpha$ is the charge transfer coefficient, $n_{e}$ number of electrons and $F$ is the Faraday's constant, $T$ is the operating temperature of the fuel cell, $m$ and $n$ are two constant, $t_{e l e}$ is the thickness of the electrode and $\kappa$ is the conductivity of phosphoric acid solution. The Output voltage of the PAFC is expressed as [5]:

$$
U_{f}=U_{r e v}-U_{a c t}-U_{c o n}-U_{o h m}
$$


Journal of Thermal Engineering, Research Article, Vol. 5, No. 2, Special Issue 9, pp. 29-45, February, 2019

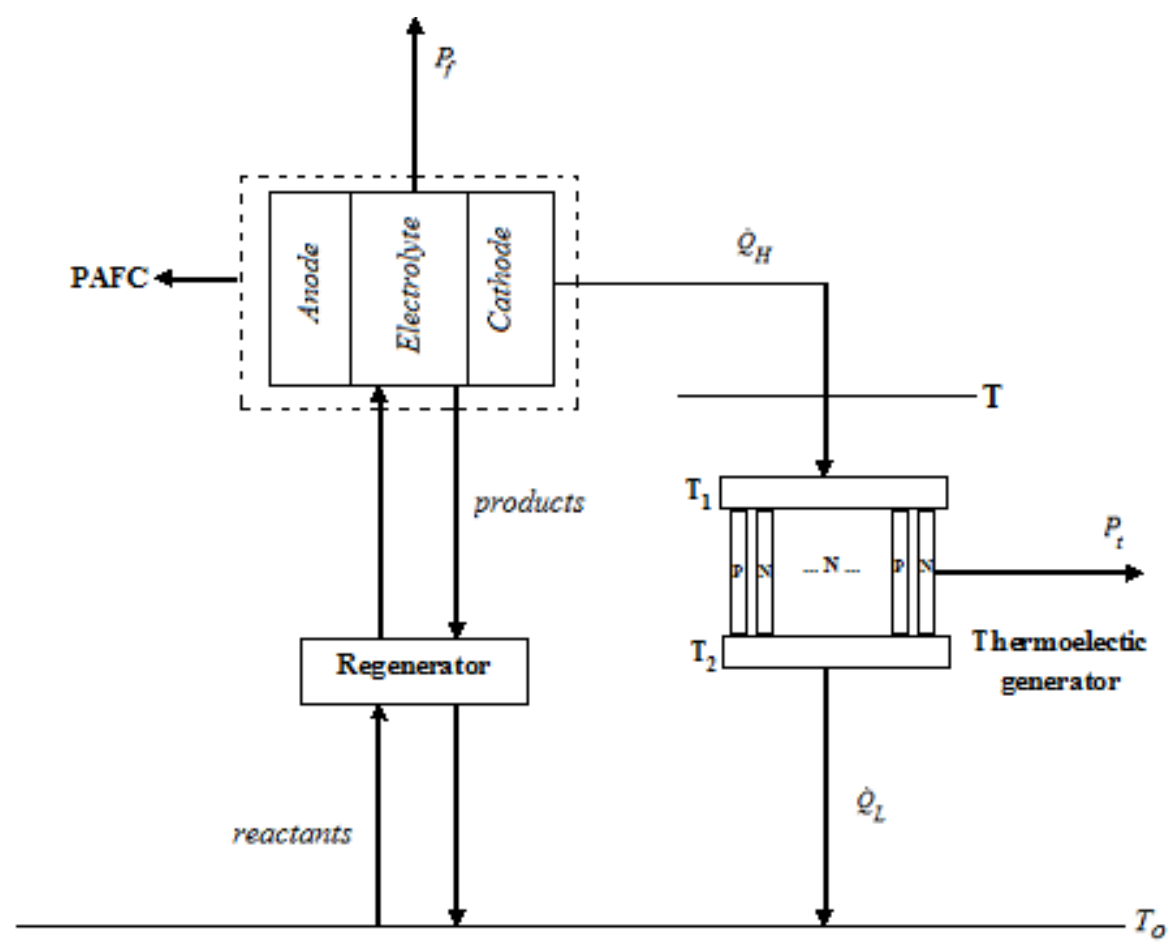

Figure 1. PAFC - thermoelectric generator hybrid system.

Power output and efficiency of the PAFC are calculated as eqs. (6,7) [5]:

$$
\begin{gathered}
P_{f}=U_{f} j A \\
\eta_{f}=\frac{P_{f}}{-\Delta \dot{H}}
\end{gathered}
$$

where $A$ is the polar plate area, $-\Delta \dot{H}$ is the total energy provided to fuel cell per unit time and $\Delta h$ is the molar enthalpy change at the operating temperature. $-\Delta \dot{H}$ is described in eq. (8) [5]:

$$
-\Delta \dot{H}=-\frac{j A \Delta h}{n_{e} F}
$$

Exergy efficiency of the PAFC is:

$$
\varphi_{f}=\frac{P_{f}}{-\Delta \dot{G}}
$$

where $-\Delta \dot{G}$ Gibbs energy change per unit time and $\Delta g$ is the molar Gibbs energy change. $-\Delta \dot{G}$ is defined as [1]:

$$
-\Delta \dot{G}=-\frac{j A \Delta g}{n_{e} F}
$$


Exergy destruction rate of the fuel cell is [3]:

$$
\operatorname{Exd}_{f}=\left(-\frac{\Delta h}{n_{e} F a}-U_{\text {cell }}\right) j A
$$

Heat transfer occurred in the regenerator is [6]:

$$
\dot{Q}_{r}=\theta\left(1-\varepsilon_{\mathrm{r}}\right)\left(T-T_{o}\right)
$$

where $\theta$ heat conductance, $\varepsilon_{r}$, regenerator effectiveness and $T_{o}$ is the ambient temperature. Heat released from the fuel cell is:

$$
\dot{Q}_{H, f}=-\Delta \dot{H}-P_{f}-\dot{Q}_{r}
$$

Secondly analysis of the thermoelectric generator must be performed. Heat input of thermoelectric generator can be defined in eqs. (14) and (16) [36]. These are equal as well as heat rejected from the PAFC in eq. (13). Heat rejected form the thermoelectric generator is shown in eqs. (15) and (17) [36].

$$
\begin{gathered}
\dot{Q}_{H, t}=N\left(\beta I T_{1}-I^{2} \frac{r}{2}+K\left(T_{1}-T_{2}\right)\right) \\
\dot{Q}_{L, t}=N\left(\beta I T_{2}+I^{2} \frac{r}{2}+K\left(T_{1}-T_{2}\right)\right) \\
\dot{Q}_{H, t}=k_{H} a_{t}\left(T-T_{1}\right) \\
\dot{Q}_{L, t}=k_{L} a_{t}\left(T_{2}-T_{o}\right)
\end{gathered}
$$

Power supplied from the thermoelectric generator is:

$$
P_{t}=\dot{Q}_{H, t}-\dot{Q}_{L, t}
$$

where $\beta$ is Seebeck coefficient, $T_{1}$ is the temperature of the hot junction, $T_{2}$ is the temperature of the cold junction, $N$ is the number of thermoelectric units, $I$ is the electrical current generating in semi- conductor couple, $r$ is the electrical resistance, $K$ is the thermal conductance of the semi-conductance couple, $k_{H}$ and $k_{L}$ are the heat transfer coefficients and $a_{t}$ is the heat transfer area of the heat exchangers. In this study, calculations are conducted for maximum power output of the thermoelectric generator. Optimum electrical current for maximum power can be defined as [36]:

$$
I=\frac{\beta\left(T_{1}-T_{2}\right)}{2 r}
$$

Number of modules required to heat input can be calculated by equalizing eqs. (14) and (16): 
Journal of Thermal Engineering, Research Article, Vol. 5, No. 2, Special Issue 9, pp. 29-45, February, 2019

$$
N=\frac{8 a_{t} k_{H} r\left(T-T_{1}\right)}{\left(T_{1}-T_{2}\right)\left(8 K r+\beta^{2}\left(3 T_{1}+T_{2}\right)\right)}
$$

Similarly $T_{2}$ is solved by equalizing eqs. (15) and (17) and result is:

$$
\begin{aligned}
& T_{2}=\frac{3 \beta^{2} k_{H} T-8 K k_{L} r-3 \beta^{2} k_{H} T_{1}-3 \beta^{2} k_{L} T_{1}+\beta^{2} k_{L} T_{o}}{2 \alpha^{2} k_{L}} \\
& +\frac{\sqrt{\left(8 K k_{L} r+\beta^{2}\left(3 k_{H} T_{1}-3 k_{H} T+3 k_{L} T_{1}-k_{L} T_{o}\right)\right)^{2}+4 \beta^{2} k_{L}\left(8 K r\left(k_{H}\left(T-T_{1}\right)+k_{L} T_{o}\right)+\beta^{2} T_{1}\left(k_{H}\left(T-T_{1}\right)+3 k_{L} T_{o}\right)\right)}}{2 \beta^{2} k_{L}}
\end{aligned}
$$

Finally, $T_{l}$ is defined as using (13) and (16):

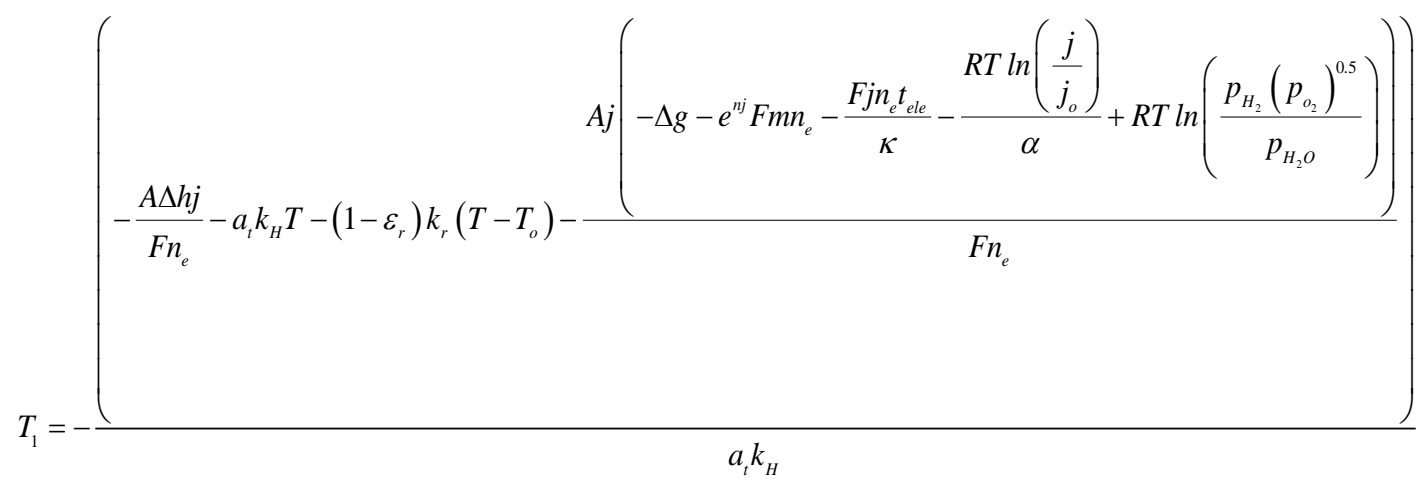

Thermoelectric properties depending on temperature are shown in (23) - (28) [35]:

$$
\begin{gathered}
\beta=2 \times\left(22224+930.6 T_{m}-0.9905 T_{m}^{2}\right) \times 10^{-9} \\
\rho=\left(5112+163.4 T_{m}-0.6279 T_{m}^{2}\right) \times 10^{-10} \\
\lambda=\left(62605-277.7 T_{m}+0.413 T_{m}^{2}\right) \times 10^{-4} \\
T_{m}=\left(\frac{T_{1}+T_{2}}{2}\right) \\
r=\left(\frac{\rho L_{1}}{A_{1}}+\frac{\rho L_{2}}{A_{2}}\right) \\
K=\left(\frac{\lambda A_{1}}{L_{1}}+\frac{\lambda A_{2}}{L_{2}}\right)
\end{gathered}
$$


where $T_{m}$ is the mean temperature, $L_{l}$ is the length of $\mathrm{p}$ type material, $L_{2}$ is the length of $\mathrm{n}$ type material and, similarly, $A_{l}$ is the area of $\mathrm{p}$ type material, $A_{2}$ is the length of $\mathrm{n}$ type material. Efficiency and reversible power of the thermoelectric generator are shown in eqs. (29) and (30) respectively.

$$
\begin{gathered}
\eta_{t}=\frac{P_{t}}{\dot{Q}_{H, t}} \\
P_{r e v, t}=Q_{H, t}\left(1-\frac{T o}{T}\right)-Q_{L, t}\left(1-\frac{T o}{T_{L}}\right)
\end{gathered}
$$

Exergy efficiency and exergy destruction rate are expressed in eqs. (31) and (32) respectively.

$$
\begin{gathered}
\varphi_{t}=\frac{P_{t}}{P_{r e v, t}} \\
\operatorname{Exd}_{t}=T_{o}\left(\frac{\dot{Q}_{L, t}}{T_{L}}-\frac{\dot{Q}_{H, t}}{T}\right)
\end{gathered}
$$

Finally, thermodynamic parameters for PAFC- thermoelectric generator is shown in (33) - (36). These are power output, efficiency, exergy efficiency and exergy destruction rate respectively.

$$
\begin{gathered}
P_{h y}=P_{f}+P_{t} \\
\eta_{h y}=\frac{P_{h y}}{-\Delta \dot{H}} \\
\varphi_{t}=\frac{P_{h y}}{-\Delta \dot{G}+P_{r e v, t}} \\
\operatorname{Exd}_{h y}=\operatorname{Exd}_{f}+\operatorname{Exd}_{t}
\end{gathered}
$$

Firstly, hybrid system is investigated by using thermoeconomic method called EXCEM [54] where EC is ratio of thermodynamic loss rate (in this paper exergy loss rate, which is described as is ratio of rate, which is difference of exergy output from the exergy input, is considered) to capital cost [54].

$$
E C_{k}=\frac{(\text { Exergy loss rate })_{k}}{Z_{k}}
$$

Where $Z$ is the capital cost of the system and it is calculated by multiplying unit cost (c) for per $\mathrm{kW}$ and power output of the considered system:

$$
Z_{k}=P_{k} c_{k}
$$


Another economic evaluation criteria is the total cost of the system and it is defined as [55]:

$$
\dot{C}_{k}=\dot{Z}_{k}+\dot{C}_{f u e l}
$$

where $\dot{Z}_{k}$ is capital cost to per unit of time [55]:

$$
\dot{Z}_{k}=\frac{Z_{k} C R F \Phi}{N}
$$

where $C R F$ is the capital recovery factor, $\Phi$ is the maintenance factor and $N$ is the operating hours in a year $[55]$.

$$
C R F=\frac{i n(1+i n)^{l t}}{(1+i n)^{l t}-1}
$$

In eq. (41), in represents interest rate and $l t$ is the life time of the considered system. Fuel cost to per unit time is shown eq. (42), where $c_{\text {fuel }}$ is unit cost of fuel, $L H V$ lower heating value of the fuel and $\dot{m}_{\text {fuel }}$ is mass flow rate of the fuel [55]:

$$
\dot{C}_{f u e l}=c_{f u e l}\left(\frac{L H V}{1000}\right) \dot{m}_{f u e l}
$$

mass flow rate is calculated as eq (43):

$$
\dot{m}_{f u e l}=\left(1.05 \times 10^{-8}\right) \frac{P_{f}}{U_{f}}
$$

In calculations, parameters in eqs.(38)-(43), specific cost of the PAFC $\left(c_{f}\right)$ is 4\$/W[56,57], specific cost of thermoelectric generator $\left(c_{t}\right)$ is $11.92 \$ / \mathrm{W}$ [58], interest rate is $10 \%$, operating house in a year is 8200 hour [55], $\Phi$ is 1.06 [55], specific cost of the fuel $\left(c_{f u e l}\right)$ is $10 \$ / G J$ [59], lower heating value of the fuel is $120.7 \mathrm{MJ} / \mathrm{kg}$.

\section{RESULTS AND DISCUSSION}

Results obtained from calculations are shown in figs. 2-10. Parameters used in the calculations are listed in table 1 and 2 which is given from the refs. [5-7, 35-37]. Results are presented as power density $(p=P / A)$ and exergy destruction density (exd $=E x d / A)$ for power output and exergy rate.

One can be seen the change of power densities with current density in fig 2 . As it is shown, all power outputs have an optimum (maximum) point. Power density of hybrid system reaches its maximum at $j=10200 \mathrm{Am}^{-2}$ and it is equal to $8735.340 \mathrm{Wm}^{-2}$. When investigating power densities for PAFC and thermoelectric generator, it is seen that they have optimum points too. These points are provided at $j=10100 \mathrm{Am}^{-2}$ with $8538.440 \mathrm{Wm}^{-2}$ for PAFC and at $j=12500 \mathrm{Am}^{-2}$ with $351.036 \mathrm{Wm}^{-2}$ value for TEG. Changes of hybrid system and PAFC are parabolic, however, TEG increases nearly linear about $j=8500 \mathrm{Am}^{-2}$ after this point it changes logarithmically and reaches its optimum. 

2019

Table 1. Parameters used in PAFC [5-7, 37].

\begin{tabular}{|c|c|c|}
\hline Parameter & Unit & Value \\
\hline$p_{\mathrm{H}_{2}}, p_{\mathrm{H}_{2} \mathrm{O}}$ & atm & 1.0347 \\
\hline$p_{\mathrm{O}_{2}}$ & atm & 0.21 \\
\hline$n e$ & - & 2 \\
\hline$\alpha$ & - & 1 \\
\hline$j_{o}$ & $A m^{-2}$ & $6 \times 10^{-2}$ \\
\hline$t_{\text {ele }}$ & $m$ & $1 \times 10^{-6}$ \\
\hline$\kappa$ & $m h^{-1}$ & 3.63 \\
\hline$m$ & - & $3 \times 10^{-5}$ \\
\hline$n$ & - & $8 \times 10^{-4}$ \\
\hline$F$ & $C / m o l$ & 96485 \\
\hline$R$ & $\mathrm{~J} / \mathrm{molK}^{-}$ & 8.314 \\
\hline$\Delta g$ & $\mathrm{~J} / \mathrm{mol}$ & -228610 \\
\hline$\Delta h$ & $\mathrm{~J} / \mathrm{mol}$ & -243342 \\
\hline$T$ & $K$ & 473.15 \\
\hline$e p r$ & - & 0.85 \\
\hline$T o$ & $K$ & 293.15 \\
\hline \multicolumn{2}{|r}{}
\end{tabular}

Table 2. Parameters used in thermoelectric generator $[35,36]$.

\begin{tabular}{|c|c|c|}
\hline Parameter & Unit & Value \\
\hline$k_{H}, k_{L}$ & $\mathrm{Wm}^{-2}$ & 170 \\
\hline$a_{t}$ & $\mathrm{~m}^{2}$ & 1 \\
\hline$L_{1}, L_{2}$ & $\mathrm{~mm}$ & 6 \\
\hline$A_{1}, A_{2}$ & $\mathrm{~m}^{2}$ & 0.0001 \\
\hline
\end{tabular}

In figure 3 energy efficiencies are illustrated. As it is seen that they have no optimum point, their maximum values are obtained at minimum current density. Maximum efficiencies of hybrid system, PAFC and TEG are $81.35 \%, 81.28 \%$ and $5.51 \%$ respectively. Effect of TEG on the hybrid system increases at higher current densities, however, average effect of it on the hybrid system is about $2 \%$.

Variation of exergy efficiencies are in fig. 4. Curves in the fig 4. is very similar in fig.3. Maximum exergy efficiencies are obtained at minimum current density and the bigger current density means the lower exergy efficiency. Maximum exergy efficiency of hybrid system is $86.6 \%, 86.5 \%$ for the PAFC and $14.9 \%$ for the TEG. Comparing results of energy and exergy efficiencies, it can be seen that exergy efficiencies bigger than energy efficiencies. However, effect of the TEG on the hybrid system in terms of the exergy efficiency is same with effect of the energy efficiency.

Exergy destruction densities changes are shown in fig.5. All exergy densities grow up with current density and this change nearly linear until $j=10000 \mathrm{Am}^{-2}$, after this point they increase dramatically. Their maximums, which are at $j=12900 \mathrm{Am}^{-2}, 21473 \mathrm{Wm}^{-2}$ for the hybrid system, $15925 \mathrm{Wm}^{-2}$ for the PAFC and $5548 \mathrm{Wm}^{-2}$ for the TEG.

Total cost rate of the hybrid system, PAFC and TEG are indicated in fig. 6. Total cost rates of hybrid system and PAFC have an critical (maximum point) contrast to TEG. Total cost of hybrid system and PAFC increase until their critical point and then they begin to decrease. Their critical point are obtained at $j=10900$ 
Journal of Thermal Engineering, Research Article, Vol. 5, No. 2, Special Issue 9, pp. 29-45, February, 2019

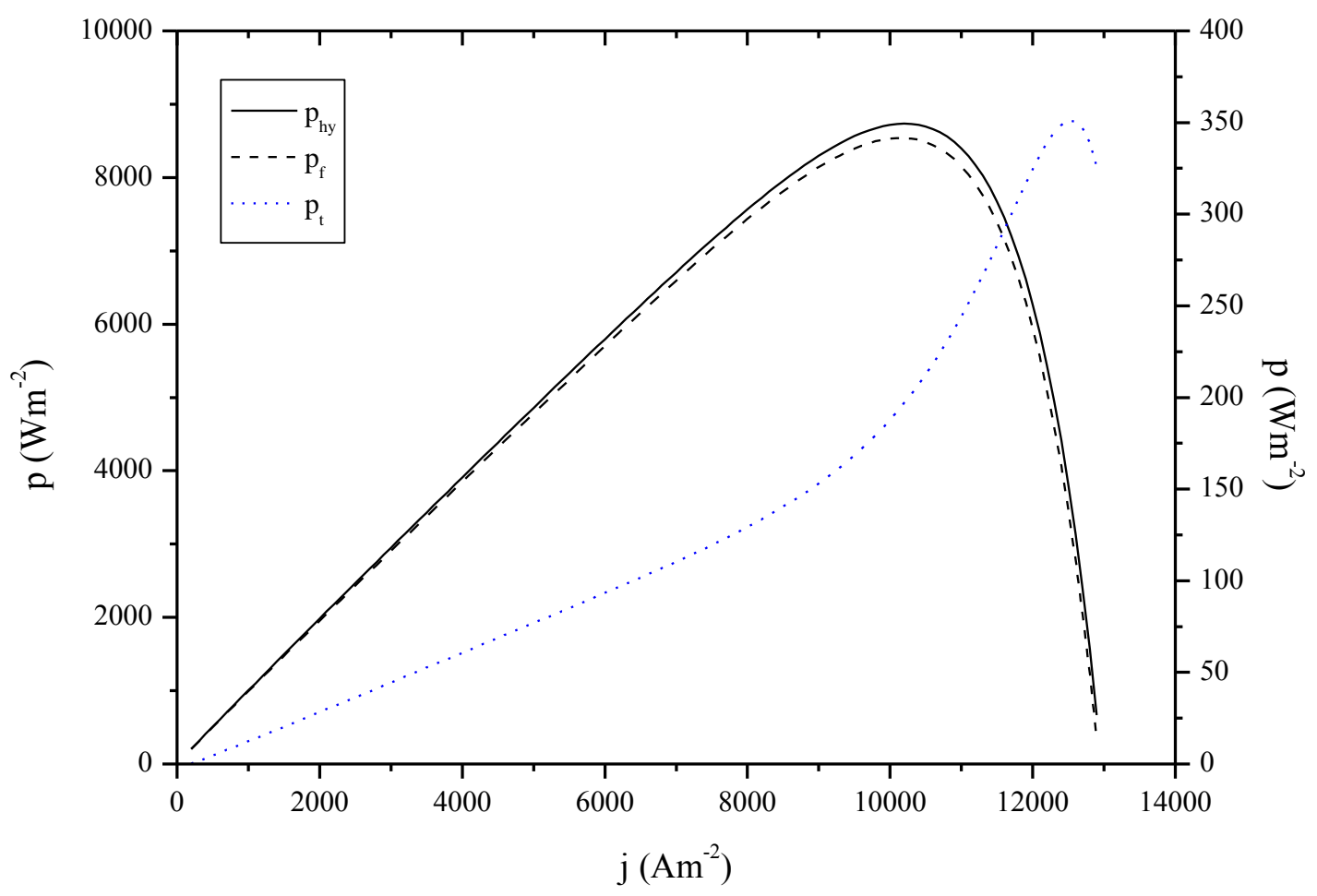

Figure 2. Variation of power density with current density.

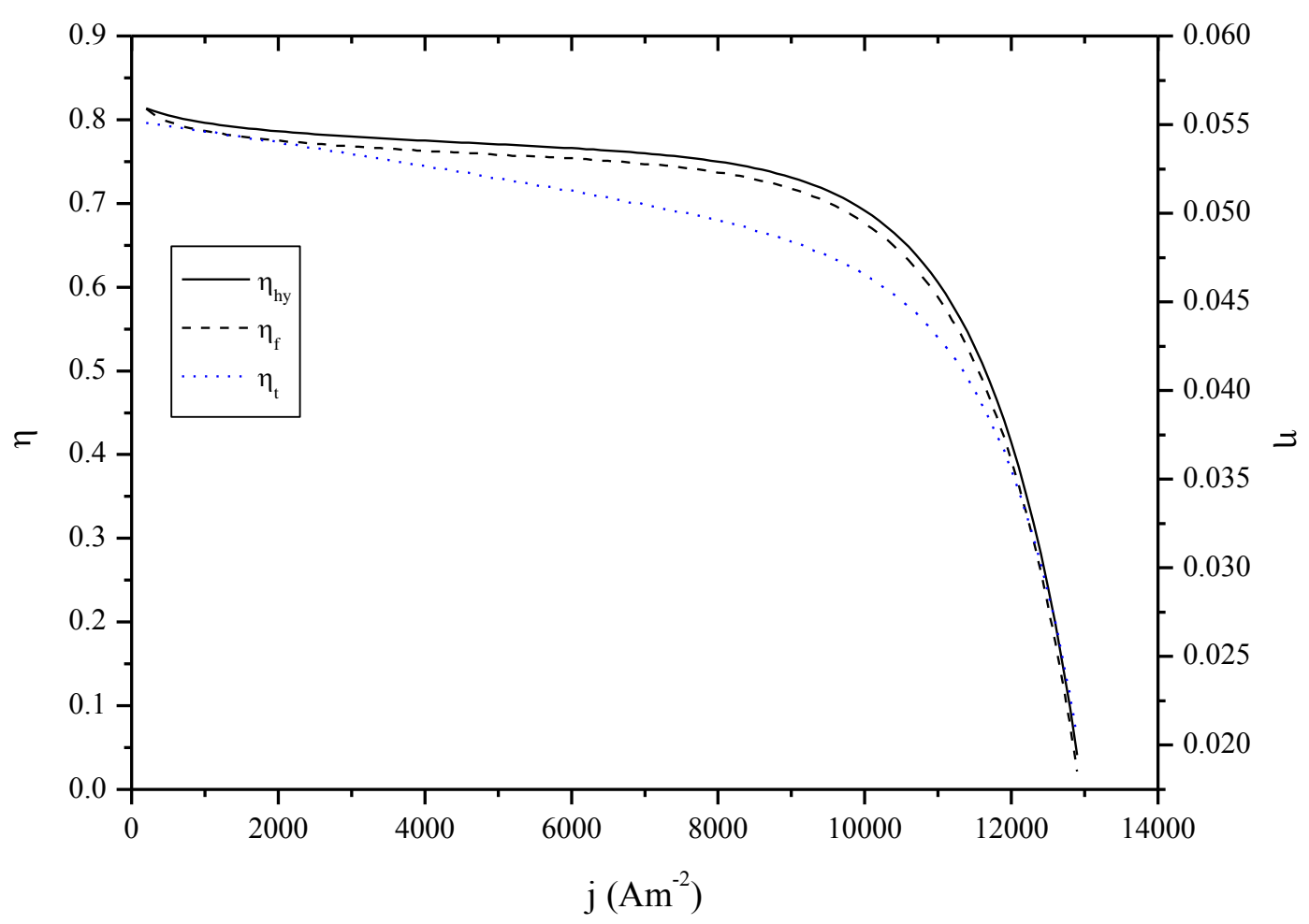

Figure 3. Variation of energy efficiency with current density.

$\mathrm{Am}^{-2}$ for the hybrid system and $j=10800 \mathrm{Am}^{-2}$ for the PAFC and corresponding values are $0.633 \$ \mathrm{~h}^{-1}$ and $0.606 \$ \mathrm{~h}^{-1}$ respectively. The maximum total cost value of TEG is obtained at $j=12900 \mathrm{Am}^{-2}$ with $0.389 \$ \mathrm{~h}^{-1}$. 
Journal of Thermal Engineering, Research Article, Vol. 5, No. 2, Special Issue 9, pp. 29-45, February, 2019

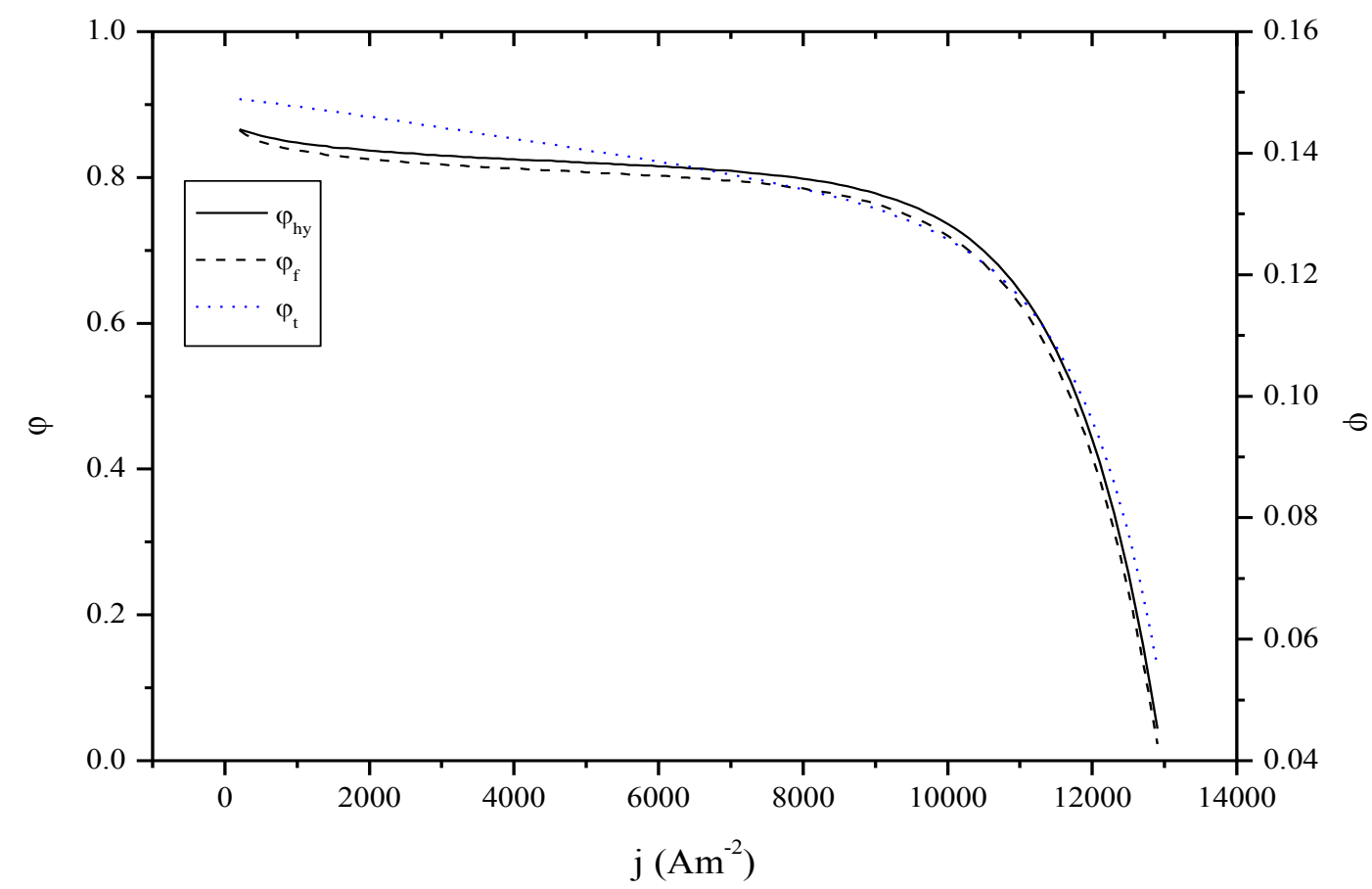

Figure 4.Variation of exergy efficiency with current density.

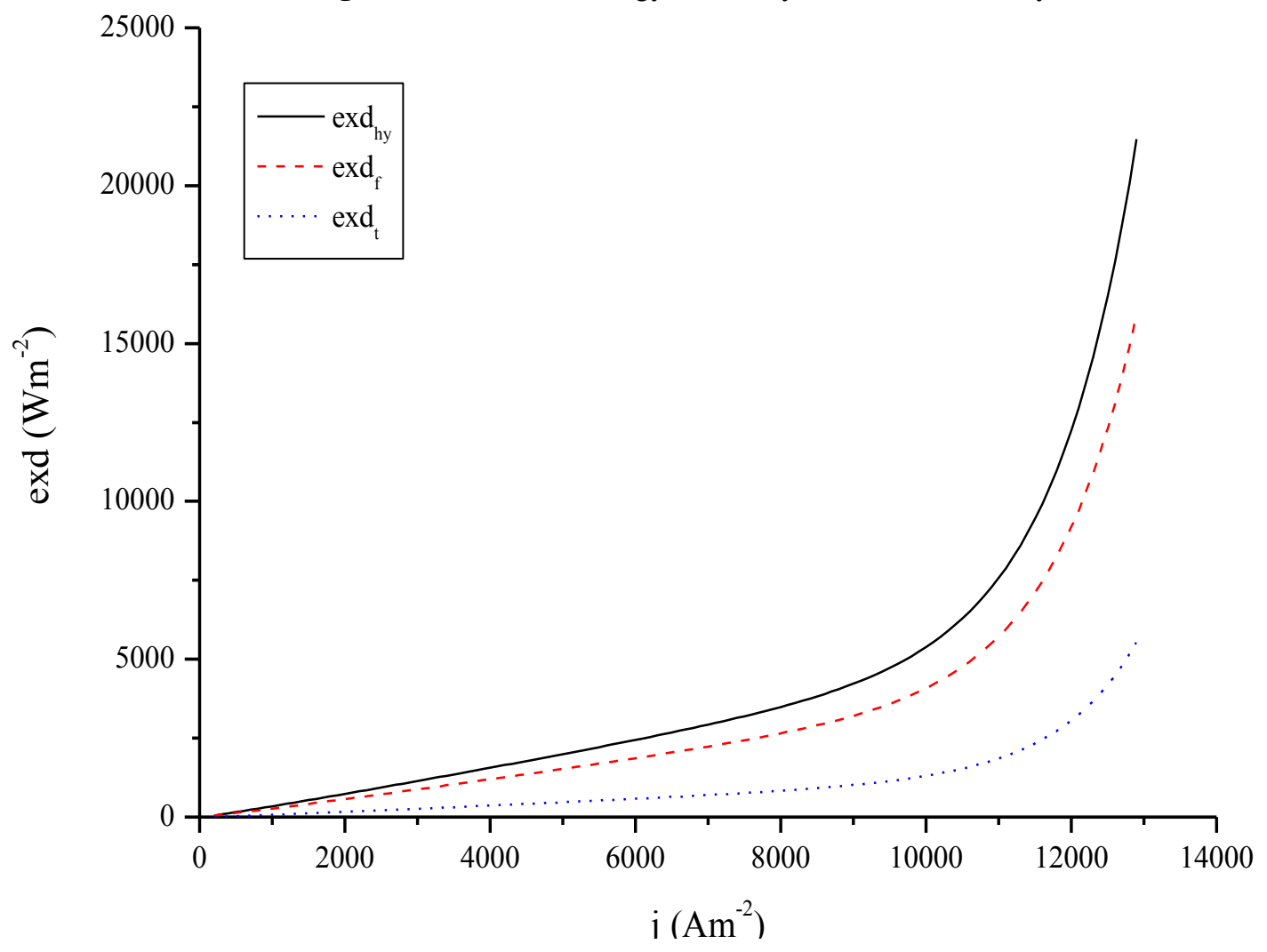

Figure 5. Variation of exergy destruction rate with current density.

$E C$ of the considered systems can be shown in fig.7.EC of all considered systems show similar tendency. $E C$ of hybrid system and the TEG rise up nearly linear about $j=11000 \mathrm{Am}^{-2}$ and this change is very slow, after this point they increase importantly. Similarly EC of PAFC increases nearly linear until $j=12000 \mathrm{Am}^{-2}$ after this point, it grows up dramatically. Maximum values of hybrid system, PAFC and TEG are $2.782 \mathrm{~W}^{-1}, 10.922 \mathrm{~W} \$$ ${ }^{1}, 2.491 \mathrm{~W}^{-1}$ respectively and change in them are $98.6 \%, 99.6 \%$ and $64.9 \%$ respectively. 


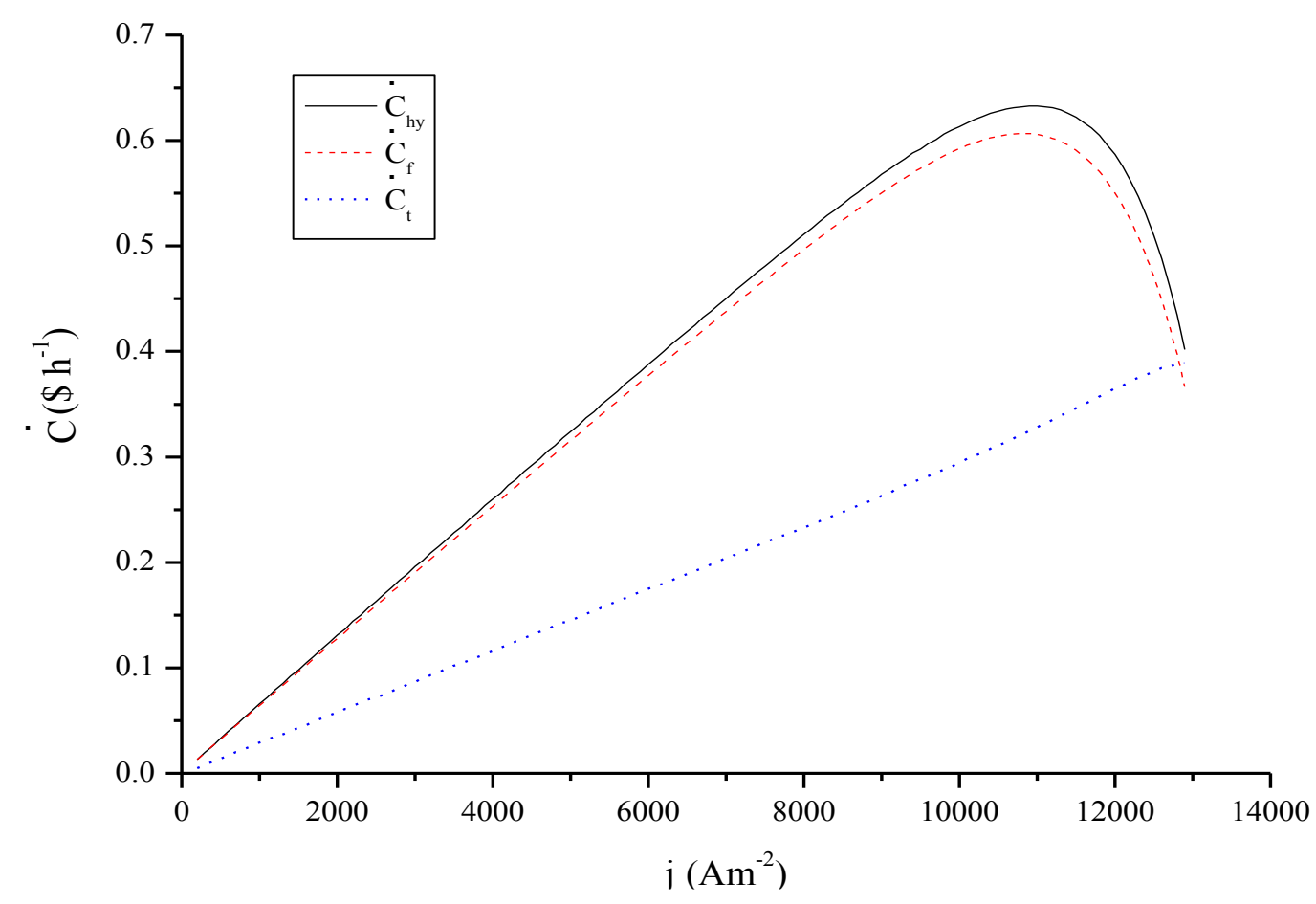

Figure 6. Variation of cost rate with current density.

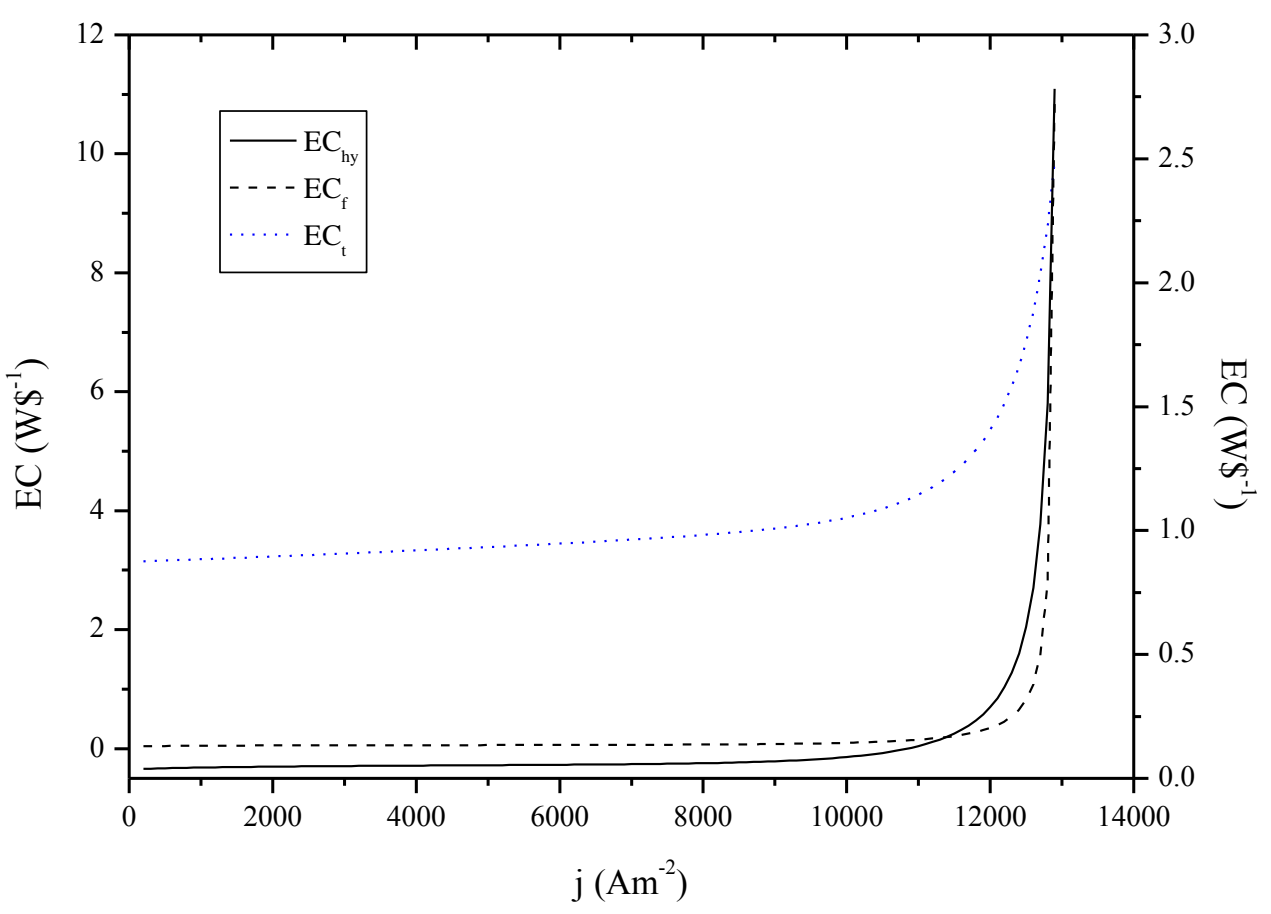

Figure 7. Variation of EC with current density.

$p-\eta-\varphi$ curves is shown in fig. 8 . This chart may be called as performance curve. In this graphic, energy and exergy efficiencies of hybrid system are investigated according to power density. In there, $p_{\max }, p_{\eta}, p_{\varphi}, \eta_{\max }$, $\eta_{p}, \varphi_{\max }, \varphi_{p}$ mean maximum power density, power density at the maximum energy efficiency, power density at maximum exergy efficiency, maximum energy efficiency, energy efficiency at maximum power density, maximum exergy efficiency and exergy efficiency at the maximum power density. $\eta_{p}$ and $\varphi_{p}$ are equal to $67.9 \%$ 


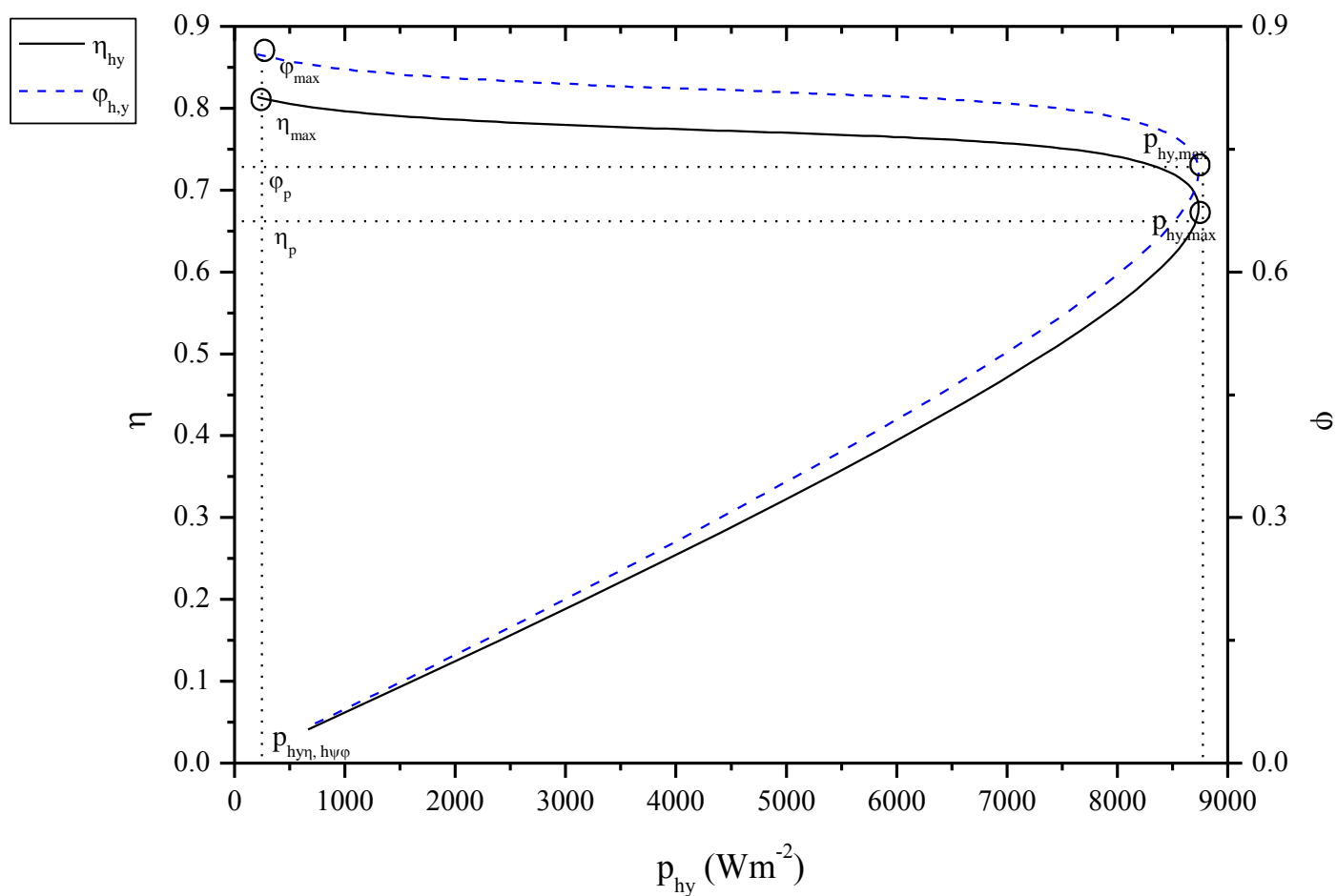

Figure 8. $p-\eta-\varphi$ curve for the hybrid system.

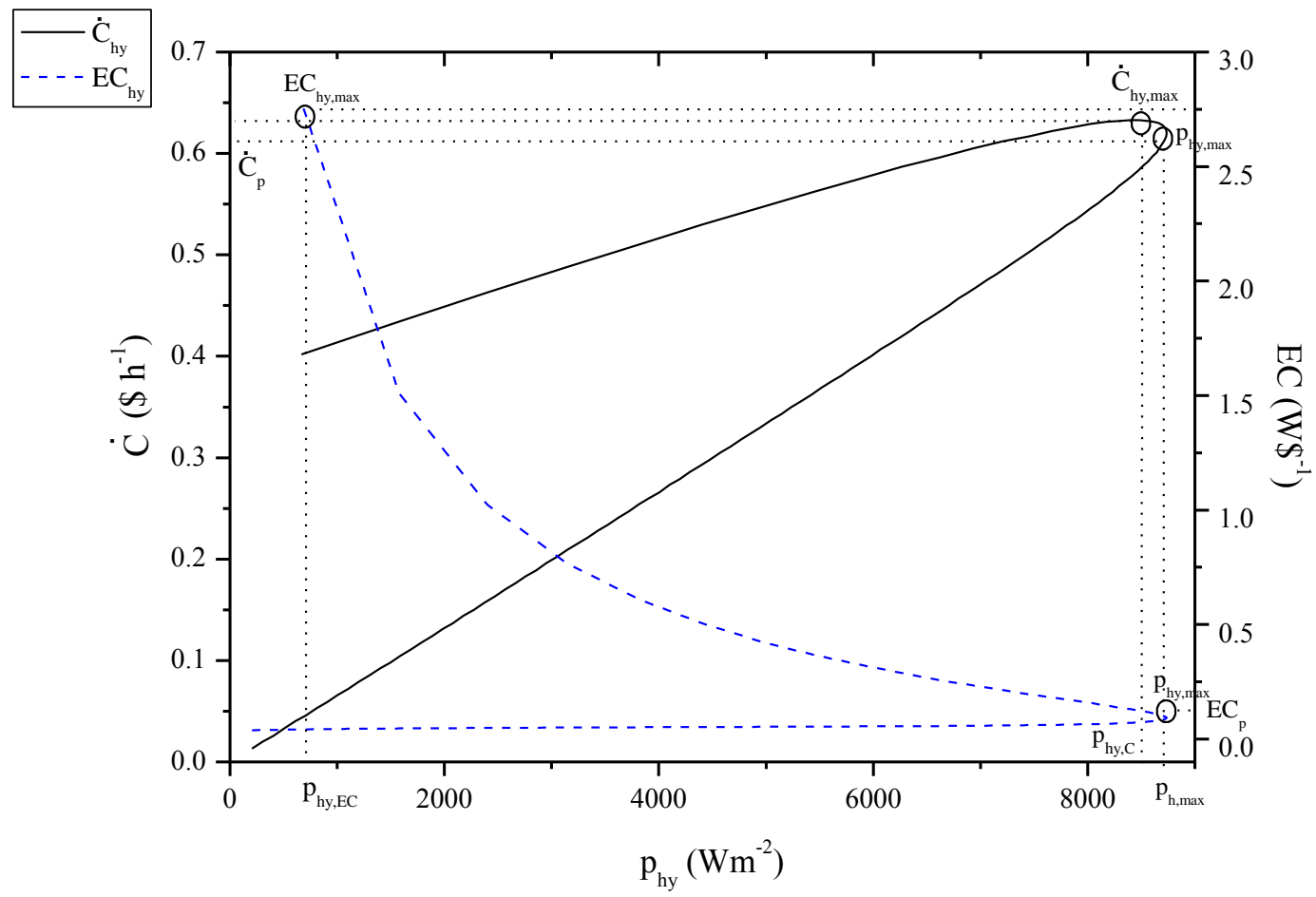

Figure 9. $\mathrm{p}-\dot{C}$-EC curve for the hybrid system.

and $72.3 \%$, these values correspond to $82.7 \%$ and $83.4 \%$ of their maximum respectively. $p_{\eta}$ and $p_{\varphi}$ are equal to each other and their values are $205.173 \mathrm{Wm}^{-2}$ and it is equal to only $2.3 \%$ of the maximum power density.

$p-\dot{C}-E C$ curves can be shown in fig.9 where $p_{C}, p_{E C}, \dot{C}_{\max }, \dot{C}_{p}, E C_{\max }, E C_{p}$ represent to power density at total cost rate, power density at $E C$, maximum total cost rate, total cost rate at power density, maximum exergy loss rate and $E C$ at maximum power density respectively. $p_{C}$ is equal to $8485.99 \mathrm{Wm}^{-2}$ which is $97.1 \%$ of the maximum power density and $p_{E C}$ is $8397.20 \mathrm{Wm}^{-2}$ which is equal to $96.1 \%$ of the maximum power density. 


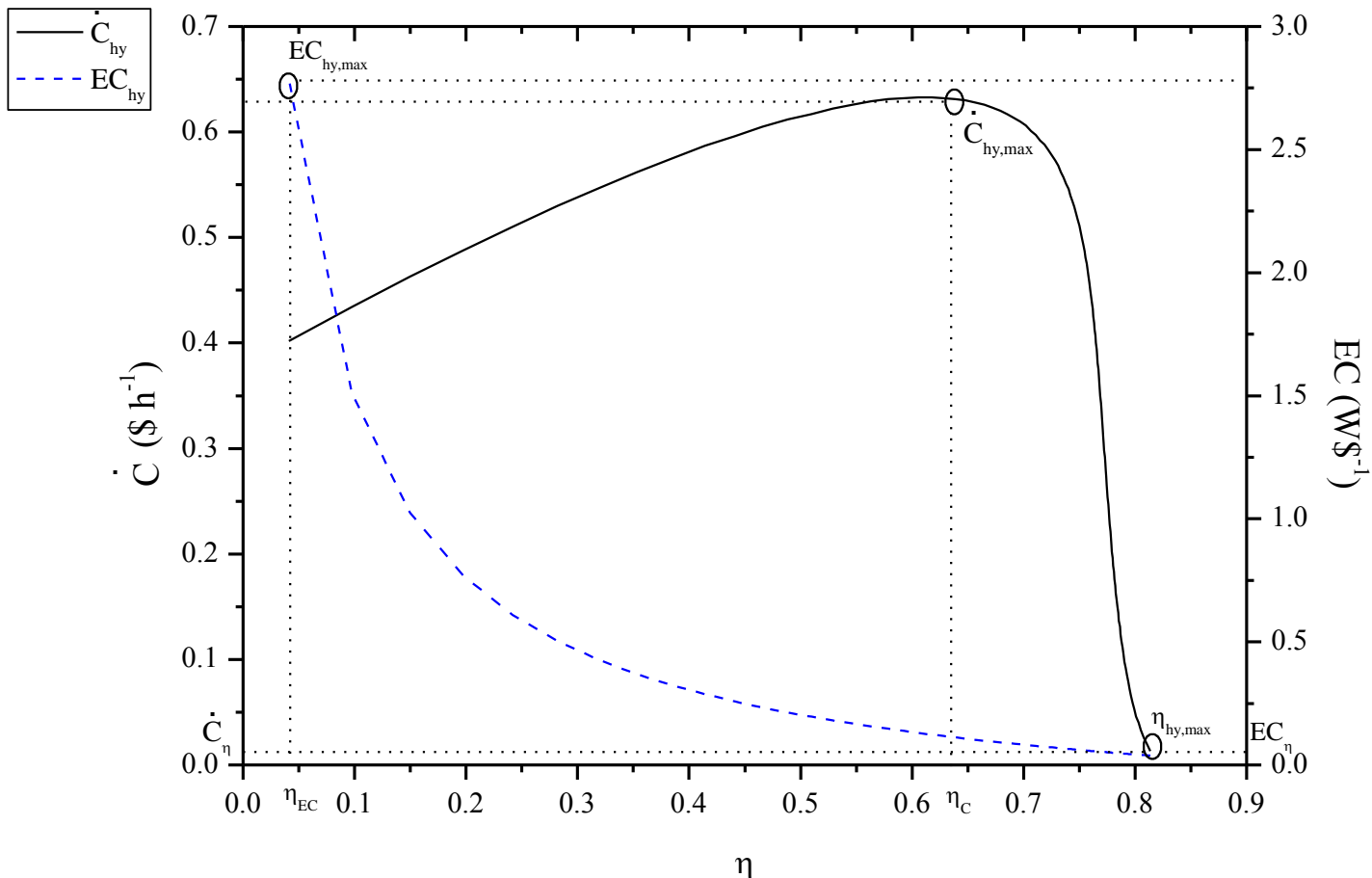

Figure 10. $\eta-\dot{C}$-EC curve for the hybrid system.

Similarly, $\dot{C}_{p}$, is 0.620 and it is $98 \%$ of the maximum total capital cost rate and $E C_{p}$ is equal to $0.0917 \mathrm{~W}^{-1}$ which is only $3.3 \%$ of the maximum $E C$.

Finally, $\eta-\dot{C}-E C$ chart is indicated in fig.10 where $\eta_{C}, \eta_{E C}, \dot{C}_{\max }, \dot{C}_{\eta}, E C_{\max }, E C_{\eta}$ are energy efficiency at the maximum total capital cost rate, energy efficiency at the maximum $E C$, maximum total capital cost rate, total capital cost rate at the maximum energy efficiency, maximum $E C$ and $E C$ the maximum energy efficiency respectively. $\eta_{C}$ and $\eta_{E C}$ are $61.7 \%$ and $4.1 \%$, these values correspond to $75.8 \%$ and $5 \%$ of the maximum efficiency. In addition to that $\dot{C}_{\eta}$ and $E C_{\eta}$ are $0.013 \$ \mathrm{~h}^{-1}$ and $0.039 \mathrm{~W} \$^{-1}$, these values are $2 \%$ and $1.4 \%$ of their maximum.

\section{CONCLUDING REMARKS}

In this paper, a PAFC-TEG hybrid system is investigated in terms of its performance, economical and thermoeconomic aspects. Some important results are listed follows:

- Maximum power density of the hybrid system is $8735.340 \mathrm{Wm}^{-2}$ at $j=10200 \mathrm{Am}^{-2}$

-Maximum energy efficiency of the hybrid system is $81.35 \%$ at low current densities, effect of TEG on the hybrid system $2 \%$ on average. Maximum exergy efficiency of the hybrid system is $86.6 \%$, and it is obtained at low current densities similar to energy efficiency.

- The maximum total cost of the hybrid system is obtained $j=10900 \mathrm{Am}^{-2}$ and this cost is equal to 0.633 $\$ \mathrm{~h}^{-1}$

-The maximum $E C$ of hybrid system is $10.922 \mathrm{~W} \$^{-1}$.

- Exergy loss rate of the hybrid system increases dramatically at $j=11000 \mathrm{Am}^{-2}$ and it is equal to 15925 $\mathrm{Wm}^{-2}$.

As it is shown where the maximum power density, the total cost rate is maximum too, until $11000 \mathrm{Am}^{-2}$ exergy lost rate does not change so importantly. In addition to these, energy efficiency, exergy efficiency and exergy destruction rate are high and the total cost rate, exergy loss rate have low values at the small current densities. According to these results, current densities should be chosen as low as possible in terms of economic aspects, economical and thermoeconomic analyses are recommended to be conducted for fuel cell hybrid systems. 


\section{ACKNOWLEDGEMENTS}

Authors would like to thank the reviewers for their valuable comments, which have been utilized in improving the quality of the paper.

\section{NOMECLATURE}

\begin{tabular}{|c|c|}
\hline$A$ & polar rate area $\left[\mathrm{m}^{2}\right]$ \\
\hline$a$ & heat transfer area $\left[\mathrm{m}^{2}\right]$ \\
\hline$c$ & unit cost for per $\mathrm{kW}\left[\$ \mathrm{~kW}^{-1}\right]$ \\
\hline$\dot{C}$ & heat capacity $\left[\$ h^{-1}\right]$ \\
\hline$C R F$ & Capital recovery factor \\
\hline EC & ratio of thermodynamic loss rate to capital cost $\left[\mathrm{kW}^{-1}\right]$ \\
\hline exd & exergy destruction density $\left[\mathrm{Wm}^{-2}\right]$ \\
\hline Exd & exergy destruction rate $[\mathrm{W}]$ \\
\hline$F$ & Faraday constant $\left[\mathrm{Cmol}^{-1}\right]$ \\
\hline$\Delta g$ & change of the molar Gibbs free energy $\left[\mathrm{Jmol}^{-1}\right]$ \\
\hline$\Delta \dot{G}$ & change rate of the molar Gibbs free energy $[\mathrm{W}]$ \\
\hline$\Delta h$ & change of the molar enthalpy $\left[\mathrm{Jmol}^{-1}\right]$ \\
\hline$\Delta \dot{H}$ & change rate of the enthalpy [W] \\
\hline$I$ & electrical current generating in semi-conductance couple $[\mathrm{A}]$ \\
\hline$j$ & current density $\left[\mathrm{Am}^{-2}\right]$ \\
\hline$k$ & heat transfer coefficient $\left[\mathrm{W} \mathrm{m}{ }^{-2} \mathrm{~K}^{-1}\right]$ \\
\hline$K$ & heat conductance of the semi-conductance couple $\left[\mathrm{W} \mathrm{m}^{-1} \mathrm{~K}^{-1}\right]$ \\
\hline$L$ & length of $\mathrm{p}$ and $\mathrm{n}$ type material $[\mathrm{mm}]$ \\
\hline $\begin{array}{l}L H V \\
m\end{array}$ & $\begin{array}{l}\text { lower heating value of the fuel }\left[\mathrm{kJ} \mathrm{kg}^{-1}\right] \\
\text { a constant }\end{array}$ \\
\hline$\dot{m}$ & mass flow rate $\left[\mathrm{kgs}^{-1}\right]$ \\
\hline$n$ & number electrons and a constant \\
\hline$N$ & number of thermoelectic units and operation hours in a year $\left[\right.$ hyear $\left.^{-1}\right]$ \\
\hline$p$ & pressure $[\mathrm{atm}, \mathrm{kPa}]$, power density $\left[\mathrm{Wm}^{-2}\right]$ \\
\hline$P$ & power $[\mathrm{W}]$ \\
\hline$P A F C$ & phosphoric acid fuel cell \\
\hline$Q$ & heat rate $[\mathrm{W}]$ \\
\hline$r$ & electrical resistance of the semiconductor couple $[\Omega]$ \\
\hline$R$ & universal gas constant $\left[\mathrm{Jmol}^{-1} \mathrm{~K}^{-1}\right]$ \\
\hline$t$ & thickness [m] \\
\hline$T$ & temperature $[\mathrm{K}]$ \\
\hline$T E G$ & thermoelectric generator \\
\hline$U$ & potential $[\mathrm{V}]$ \\
\hline$Z$ & capital cost $[\$]$ \\
\hline$\dot{Z}$ & capital cost per hour $\left[\$ \mathrm{~h}^{-1}\right]$ \\
\hline \multicolumn{2}{|l|}{ Subscripts } \\
\hline act & activation \\
\hline$C$ & heat capacity \\
\hline con & concentration \\
\hline$E C$ & ratio of thermodynamic loss rate to capital cost \\
\hline$f$ & fuel cell \\
\hline$m$ & mean \\
\hline$e$ & electron \\
\hline
\end{tabular}




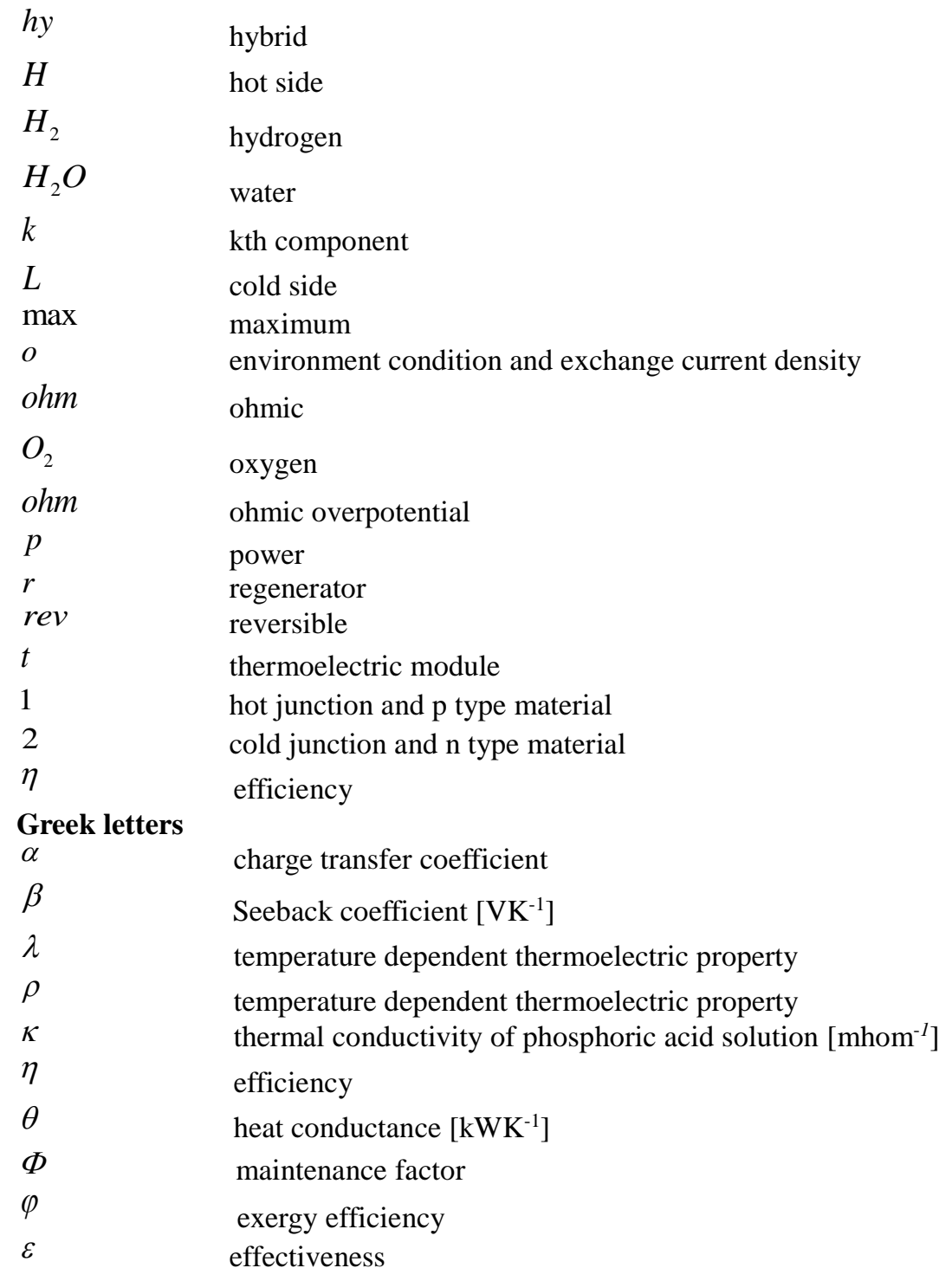

\section{REFERENCES}

[1] Zhao Y, Ou C, Chen J. (2008). A new analytical approach to model and evaluate the performance of a class of irreversible fuel cells, International Journal of Hydrogen Energy, 33, 4161 - 4170.

[2] Zhang X, Guo J, Chen J. (2010). The parametric optimum analysis of a proton exchange membrane (PEM) fuel cell and its load matching, Energy, 35, 5294-5299.

[3] Zhang H, Lin G, Chen J. (2011). Performance analysis and multi-objective optimization of a new molten carbonate fuel cell system, International Journal of Hydrogen Energy, 36, 4015 - 4021.

[4] Zhang H, Chen L, Zhang J, Chen J. (2014). Performance analysis of a direct carbon fuel cell with molten carbonate electrolyte, Energy, 68, 1-9.

[5] Zhang H, Lin G, Chen J. (2012). Multi-objective optimization analysis and load matching of a phosphoric acid fuel cell system, International Journal of Hydrogen Energy, 37, 3438-3446.

[6] Yang P, Zhang H, Hu Z. (2016). Parametric study of a hybrid system integrating a phosphoric acid fuel cell with an absorption refrigerator for cooling purposes, International Journal of Hydrogen Energy, 41, 3579 -3590.

[7] Chen X, Wang Y, Zahao Y, Zhou Y. (2016). A study of double functions and load matching of a phosphoric acid fuel cell/heat-driven refrigerator hybrid system, Energy 101, 359-365.

[8] Chen L, Zhang H,Gao S, Yan H. (2014)., Performance optimum analysis of an irreversible molten carbonate fuel cell - Stirling heat engine hybrid system, Energy 64, 923-930.

[9] Chen L, Gao S, Zhang H. (2013). Performance Analysis and Multi-Objective Optimization of an Irreversible Solid Oxide Fuel Cell-Stirling Heat Engine Hybrid System, Int. J. Electrochem. Sci., 8, 10772 - 10787.

[10]Açıkkalp E., Thermo-environmental performance analysis of irreversible solid oxide fuel cell - Stirling heat engine, International Journal of Ambient Energy, article in press DOI: 10.1080/01430750.2017.1345011. 
[11] Yang P, Zhang H. (2015). Parametric analysis of an irreversible proton exchange membrane fuel cell/absorption refrigerator hybrid system, Energy, 85, 458-467.

[12] Zhao Y, Chen J. (2009). Modeling and optimization of a typical fuel cell-heat engine hybrid system and its parametric design criteria, Journal of Power Sources, 186, 96-103.

[13] Zhang H, Lin G, Chen J. (2011). Performance Evaluation and Parametric Optimum Criteria of an Irreversible Molten Carbonate Fuel Cell-Heat Engine Hybrid System, Int. J. Electrochem. Sci,. 6, 4714 - 4729.

[14] Zhang X, Chen J. (2010). Performance analysis and parametric optimum criteria of a class of irreversible fuel cell/heat engine hybrid systems, International Journal of Hydrogen Energy 35, 284 - 293.

[15] Zhang X,Wang Y, Guo J, Shih T-M, Chen J. (2014). A unified model of high-temperature fuel-cell heat engine hybrid systems and analyses of its optimum performances, International Journal of Hydrogen Energy, 39 , $1811-1825$.

[16] Zhang X, Su S, Chen J, Zhao Y, Brandon N. (2011), A new analytical approach to evaluate and optimize the performance of an irreversible solid oxide fuel cell-gas turbine hybrid system, International Journal of Hydrogen Energy, 36, $15304-15312$.

[17] Haseli H, Dincer I, Naterer GF. (2008). Thermodynamic analysis of a combined gas turbine power system with a solid oxide fuel cell through exergy, Thermochimica Acta, 480, 1-9.

[18] Açıkkalp E. (2017). Ecologic and Sustainable Objective Thermodynamic Evaluation of Molten Carbonate Fuel Cell - Supercritical $\mathrm{CO}_{2}$ Brayton Cycle Hybrid System, International Journal of Hydrogen Energy, 42, 6272-6280.

[19] Haseli H, Dincer I, Naterer GF. (2008). Thermodynamic modeling of a gas turbine cycle combined with a solid oxide fuel cell, International Journal of Hydrogen Energy, 33, 5811 -5822.

[20] Açıkkalp E. (2017). Performance analysis of irreversible solid oxide fuel cell - Brayton heat engine with ecological based thermo-environmental criterion, Energy Conversion and Management, 148, 279-286.

[21] Zhang X, Guo J, Chen J. (2012). Influence of multiple irreversible losses on the performance of a molten carbonate fuel cell-gas turbine hybrid system, International Journal of Hydrogen Energy 37, $8664-8671$.

[22] Sánchez D, Chacartegui R, Jiménez-Espadafor F, Sánchez T. (2009). A new concept for high temperature fuel cell hybrid systems using supercritical carbon dioxide, J. Fuel Cell Sci. Technol., 6, 021306.

[23] Sanchez D, Munoz de Escalona J.M, Chacartegui R, Munoz A., Sanchez T. (2011). A comparison between molten carbonate fuel cells based hybrid systems using air and supercritical carbon dioxide Brayton cycles with state of the art technology, Journal of Power Sources, 196, 4347-4354.

[24] Zhang X, Liu H, Ni M, Chen J. (2015). Performance evaluation and parametric optimum design of a syngas molten carbonate fuel cell and gas turbine hybrid system, Renewable Energy, 80, 407-414.

[25] Mehrpooya M ,Bahramian P, Pourfayaz F, Rosen M.A. Introducing and analysis of a hybrid molten carbonate fuel cell-supercritical carbon dioxide Brayton cycle system, Sustainable Energy Technologies and Assessments 18 (2016) 100-106.

[26] Zhang H, Su S, Lin G, Chen J. (2012). Performance Analysis and Multi-Objective Optimization of a Molten Carbonate Fuel Cell Braysson Heat Engine Hybrid System, Int. J. Electrochem. Sci., 7, 3420 - 3435.

[27] Açıkkalp E. (2017). Performance analysis of irreversible molten carbonate fuel cell - Braysson heat engine with ecological objective approach, Energy Conversion and Management, 13, 2432-2437

[28] Huang C, Pan Y, Wang Y, Su G, Chen J. (2016). An efficient hybrid system using a thermionic generator to harvest waste heat from a reforming molten carbonate fuel cell, Energy Conversion and Management 121, 186193.

[29 ]Mahmoudi S.M.S., Ghavimi A.R. (2016). Thermoeconomic analysis and multi objective optimization of a molten carbonate fuel cell - Supercritical carbon dioxide - Organic Rankine cycle integrated power system using liquefied natural gas as heat sink, Applied Thermal Engineering, 107, 1219-1232.

[30] Chen L, Gong J, Sun F, Wu C. (2002). Effect of heat transfer on the performance of thermoelectric generators, Int J ThermSci, 41(1), 95-99.

[31] Meng F, Chen L, Sun F. (2010). Effects of heat reservoir temperatures on the performance of thermoelectric heat pump driven by thermoelectric generator, Int J Low-Carbon Technol,. 5(4),273-82.

[32] Meng F, Chen L, Sun F, Wu C. (2009), Thermodynamic analysis and optimisation of a new-type thermoelectric heat pump driven by a thermoelectric generator, Int J Ambient Energy, 30(2), 95-101.

[33]Chen L, Meng F, Sun F. Effect of heat transfer on the performance of thermoelectric generator-driven thermoelectric refrigerator system. Cryogenics 2012;52(1):58-65.

[34] Kaushik S, Manikandan S, Hans R. (2015). Energy and exergy analysis of thermoelectric heat pump system, Int J Heat Mass Transfer, 86, 843-52.

[35] Arora R, Kaushik SC, Arora R. (2015). Multi-objective and multi-parameter optimization of two-stage thermoelectric generator in electrically series and parallel configurations through NSGA-II, Energy, 30(91), 242254.

[36] Manikandan., Kaushik S.C. (2015). Thermodynamic studies and maximum power point tracking in thermoelectric generator-thermoelectric cooler combined system, Cryogenics, 6752-6762. 
[37] Meng F K, Chen L G, Sun F R. (2011). A numerical model and comparative investigation of a thermoelectric generator with multi-irreversibilities, Energy, 36(5), 3513-3522.

[38] Chen L G, Meng F K, Sun F R. (2012). Maximum power and efficiency of an irreversible thermoelectric generator with a generalized heat transfer law, Scientia Iranica, Transaction B: Mechanical Engineering, 19 (5), 1337-1345

[39] Chen L G, Meng F K, Sun F R. (2013). Internal and external simultaneous optimization of an irreversible multielement thermoelectric generator for maximum power output, International Journal of Low-Carbon Technologies, 8 (3), 188-196.

[40] Meng F K, Chen L G, Sun F R, Yang B. (2014). Thermoelectric power generation driven by blast furnace slag flushing water, Energy, 66, 965-972.

[41] Xiong B, Chen L G, Meng F K, Sun F R. (2014). Modeling and performance analysis of a two-stage thermoelectric energy harvesting system from blast furnace slag water waste heat, Energy, 77, 562-569.

[42] Chen L G, Meng F K, Sun F R. (2016). Thermodynamic analyses and optimizations for thermoelectric devices: the state of the arts, Science China: Technological Sciences, 59(3), 442-455.

[43] Meng F K, Chen L G, Sun F R. (2016). Effects of thermocouples physical dimension on the performance of TEG-TEH system, International Journal of Low-Carbon Technologies, 11(3), 375-382.

[44] Meng F K, Chen L G, Feng Y L, Xiong B. (2017). Thermoelectric generator for industrial gas phase waste heat recovery, Energy, 135, 83-90.

[45] Meng F K, Chen L G, Xie Z H, Ge Y L. (2017). Thermoelectric generator with air-cooling heat recovery device from wastewater, Thermal Science and Engineering Progress, 4, 106-112.

[46] Chen X , Wang Y, Cai L, Zhou Y. (2015), Maximum power output and load matching of a phosphoric acid fuel cell-thermoelectric generator hybrid system, Journal of Power Sources 294, 430-436.

[47] Zhao M , Zhang H, Hua Z, Zhang Z, Zhang J. (2015). Performance characteristics of a direct carbon fuel cell/thermoelectric generator hybrid system, Energy Conversion and Management 89, 683-689.

[48] Chen X, Chen L, Guo J, Chen J. (2011). An available method exploiting the waste heat in a proton exchange membrane fuel cell system, International Journal of Hydrogen Energy 36, 6099 - 6104.

[49] Feng H J, Chen L G, Xie Z H, Sun F R. (2015). Constructal optimization for a single tubular solid oxide fuel cell, Journal of Power Sources, 286, 406-413.

[50] Abbas S. S., Ahmadi M.H., Ahmadi M.A. (2015). Optimization performance and thermodynamic analysis of an irreversible nano scale Brayton cycle operating with Maxwell-Boltzmann gas, Energy Conversion and Management 101, 592-605.

[51] Ahmadi M H., Ahmad M.A., Pourfayaz F., Bidi M. (2016). Thermodynamic analysis and optimization for an irreversible heat pump working on reversed Brayton cycle. Energy Conversion and Management, 110, 260267.

[52] Ahmadi M.H, Ahmadi M.A,. (2016). Multi objective optimization of performance of three-heat-source irreversible refrigerators based algorithm NSGAII, Renewable and Sustainable Energy Reviews, 60, 784-794.

[53] Ahmadi M.H., Sayyaadi H, Hosseinzadeh H. (2015). Optimization of Output Power and Thermal Efficiency of Solar-Dish Stirling Engine Using Finite Time Thermodynamic Analysis, Heat Transfer-Asian Research 44, 347-376.

[54] Dincer I , Rosen M.A, Exergy: Energy, Environment and Sustainable Development, Elsevier Science, 2 edition.

[55] Aminyavari M., Haghighat A, Mamaghani A. S., Najafi B, Rinaldi F. (2016). Exergetic, economic, and environmental evaluations and multi-objective optimization of an internal-reforming SOFC-gas turbine cycle coupled with a Rankine cycle, Applied Thermal Engineering 108, 833-846.

[56] Kwak H-Y, Lee H-S, Jung J-Y, Jeon J-S, Park D-R (2004) . Exergetic and thermoeconomic analysis of a 200-kW phosphoric acid fuel cell plant, Fuel 83, 2087-2094.

[57] Staffell I, Green R. (2013). The cost of domestic fuel cell micro-CHP systems, International Journal of Hydrogen Energy, 38, 1088-1102.

[58]https://energy.gov/sites/prod/files/2015/02/f19/QTR\%20Ch8\%20\%20Thermoelectic\%20Materials\%20TA\% 20Feb-13-2015.pdf (access date, 07.04.2017).

[59] Kazim A., (2005). Exergoeconomic analysis of a PEM fuel cell at various operating conditions, Energy Conversion and Management, 46, 1073-1081. 